\title{
A Restorative Peace-making Process for Conflicted Faith Communities
}

\section{Darrell Puls}

\begin{abstract}
Restorative justice has been part of Jewish and Christian scriptures and praxis for thousands of years. Over most of this history, restorative practices were applied when one or more members of a specific faith community were found to be in theological or moral error and wished to be restored to full participation in the community. However, restorative praxis has not generally been applied to internal faith community conflicts except in certain groups with peace traditions such as Amish, Mennonite and Bruderhof. This paper briefly describes a restorative process model focusing on interpersonal forgiveness and reconciliation based on Christian scripture, research studies, and facilitative best practices.
\end{abstract}

\section{Keywords}

Peacemaking, conflict, conflicted faith communities

\section{Background of the Problem}

There are in the United States and Canada between 350,000 and 410,000 individual Christian churches, with roughly 20 percent $(70,000-82,000)$ experiencing internal conflict at any given time. In 2008, two-thirds reported that the conflict was "corrosive" or destructive (Roozen, 2008, pp.26-27) and $77.7 \%$ of churches reporting in 2010 experienced conflicts serious enough to be destructive during the previous five years (Roozen, 2015, p.7). The damage from these conflicts includes loss of members, broken relationships, congregational splits, wrecked finances, and sometimes the destruction of the conflicted church.

Mediation has been used in faith community conflicts following secular mediation praxis, with the goal of a negotiated settlement agreement. A settlement agreement is a necessary part of the process, but I offer that, while a well-written agreement can bring about a reasonable settlement of the identified issues, it cannot heal the emotional, relational, and spiritual wounds sustained in these conflicts. Church conflicts are relational far more than they are about promotions, territory, budgets, projects, and other organizational issues. Settlement agreements may serve as a map for working together in the future, but they are incapable of effectively healing the deeper wounds. The identified issues, then, are often more symptom than substance. Under these conditions, a settlement agreement may be more properly 
identified as a map outlining a continuing process of conflict management rather than a restorative or healing process, leaving the disputants resentful and suspicious, opening the gate to more conflict.

The body of church conflict literature uses secular models of mediation with scripture thrown on top, utilizing approaches such as deep dialogue (Isaacs, 1999), conflict analysis (Halverstadt, 1991), mediation (Kale, 2003), underlying issue identification (Van Yperen, 2002), family systems theory (Cosgrove, Hatfield, 1994), causation identification and intervention (Susek, 1999). While all have value, none offers a process to achieve forgiveness and reconciliation. Simply put, church and secular conflict interventionists have not known how to go beyond the secular settlement agreement to authentic forgiveness and reconciliation.

With litigation being the rarely-encouraged "first way" and mediation the "second way" of dispute resolution, restorative justice adds a "third way" as "an alternative approach to criminal justice" (Wellikoff, 2004). Some churches, such as the Church of the Brethren, have embraced an expectation that members with internal conflicts will follow the second way and invite in Peacemakers who are skilled in facilitating deep listening. Restorative justice, with its face-to-face encounters between victim and offender, is an effective means of curbing juvenile crime recidivism by "humanizing" the victim with the offender in what is commonly termed victim-offender meetings (Zehr, 1990; Umbreit, 2004, pp.292-294). Its use is now expanding into education (Stowe, 2016, pp.34-47; McGarrigle, O'Connor, 2015) and has had a major impact in the field of medical mistake litigation in the United States (Puls, 2008a). The restorative process is robust enough that it can be a valuable part in almost any conflict where there are ongoing relationships (Puls, 2008b, pp.7-9).

This paper argues for a "fourth way" that intentionally seeks relational healing as the primary goal in conflicted faith communities. The eventual settlement agreement, taking the form of a covenant, will flow from this on its own, something I have experienced several times in churches where this process was applied.

In Christianity, the local church seeks to be a community of believers who share life together (Acts, 2:43-47; 4:32-37). Faith community members tend to have shared basic assumptions: church is to be a place free from the tensions and predatory rivalries found at work and school, and they expect acceptance, accountability, discipleship, and opportunity (Vandergrift, 2013). What they do not want and do not expect - is internal fighting that splits the congregation into hostile camps. For many, open attacks within the place where they least expect it produces severe cognitive dissonance and stress. These conflicts sever friendships, destroy trust, and encourage personal attacks from unexpected places. They also break bonds that otherwise might have healing abilities (Therani, 1998, p.365). No one is exempt. They are left with three options: takes sides and join in the fight, try to stay invisible, or leave. Invisibility, however, does not protect against the silent emotional pain of seeing friends suffer, nor is it necessarily neutral as it is common to indirectly offer silent emotional support to one side or the other.

The personal and relational costs of stress induced by intense, sustained conflict are measurable: degradation of the immune system (Graham et al., 2006, p.392), generalized degeneration of physical and emotional health (Alexander, 2011, p.235), increased mortality in patients with Coronary Artery Disease 
(Celano et al., 2015, p.1110), and depression (Toussaint et al., 2012, p.383), and encourages substance abuse as a form of self-soothing. These become obvious through symptoms, e.g. digestive upset, hypertension, headaches, fatigue, crying, rage, insomnia, depression, drug addiction (Lin et al., 2004) and so on. These symptoms are key to the process. Forgiving reverses these and many more symptoms as well (Coyle and Enright, 1997; Weinberg, 1995, p.298; Fitzgibbons, 1998, p.70; Witvliet, 2001, pp.217-218; Thoreson et al, 2000, p.257).

The overwhelming conclusion in the body of literature over the last 30 years is that healthy forgiveness is a gift one gives to oneself — and that the journey from anger and revenge to peace can be guided (Enright and Fitzgibbons, 2002).

The "fourth way" combines studies on the inner workings of healthy forgiveness, group and organizational psychology, scripture, and the best practices of facilitation. It is designed to facilitate authentic forgiveness and healthy reconciliation in large group conflicts. This process goes far beyond the empowerment and recognition themes of transformational mediation (Bush et al., 1994, 2004) in both theory and practice. As third party external facilitators, we take on the role of 'Peacemakers' to work through interpersonal hurt arising from incidents of abusive behaviour and the lack of dignity/respect within a conflicted church congregation or faith community.

This paper briefly describes a new model called "The Crucible" that stands at the borderland of a vast new country, and uses an intensive group forgiveness and reconciliation process under the acronym TRUTH. The process has been vetted and field tested with excellent results. At its core is healthy forgiveness that neither condones what has happened nor condemns those involved.

Interpersonal forgiveness can be defined as a voluntary and conscious decision to release feelings of anger, pain, sadness, fear, and the desire for revenge against someone who has caused genuine harm. A more inclusive framework is needed for congregation-wide forgiveness:

Forgiveness is a process that joins moral truth, mercy, compassion, and commitment to repair torn human relationships by intentionally releasing feelings of anger, resentment, fear, and the desire for revenge. The process requires a truthful examination and turning from the past that neither ignores past wrongs nor excuses them, that neither overlooks justice nor reduces justice to revenge, that insists on the humanity of opponents even in their commission of dehumanizing deeds, that values justice that restores above justice that destroys, and that restores trust through merciful justice and mutual restoration (Puls, 2013, p.43).

\section{Preparation - Initial Contact and Engagement with the Congregation}

In my experience, initial contact comes from the pastor or chairperson of the Board of Elders, or a similar council in independent churches; and from a denominational official for affiliated churches. The contacting person generally states the "identified issues" as the problems to be solved. On the surface, these are what they have been fighting about. While interesting, the identified issues are often unintentional misdirection. As in mediation, issues are often presented as an intractable disagreement over 
something which seems inconsequential to the Peacemaker, which indicates that it is fuelled by deeper interests such as feelings of disrespect, sabotage, and betrayal. By the time churches and faith communities seek outside help, they have experienced serious cognitive dissonance between the way things are and the way they believe things were previously or "should be". The attacks on each other have grown more personal and more damaging over time until those engaged in the conflict can no longer see a path on which they travel together.

In a recent case, the problem was identified as a lack of role clarity between boards of elders and deacons, which was causing confusion and conflict. While there was some role ambiguity, I located deep anger and resentment over the way the position of Sunday School Superintendent was filled. The published hiring process had not been followed, and the wife of an elder was appointed, without an interview, over the more qualified wife of a deacon. This led to the deacon impugning the character of the elder, which in turn brought out grievances from others that widened the conflict, produced identifiable sides, and intensified their emotional investment in winning by causing the others to lose. No one identified the pastor as being part of the fight, but he was quietly manipulating others against the deacon because the deacon challenged him and "will not submit to my authority." The Pastors' goal was to force the deacon and his family to leave the church. In the end, the deacons and elders understood the pain they had caused each other, and sought mutual forgiveness. They reconciled. The pastor stormed out and resigned about a year later.

In one of my earliest cases, the fight began over a memorial shrub and who would care for it. The shrub was planted and cared for over the years by Martha in memory of her beloved, deceased husband. Now too frail to care for it, she called on the church board to assign it to a reliable person. They assigned it to the janitor, who had a drinking problem and mowed down a flower bed while intoxicated. To Martha, the shrub had deep meaning, while to the board it was just another shrub. Incensed, Martha called on friends to pressure the board members, but it backfired. The board saw this as a power play (which it was) and refused. Over time, the conflict escalated and friend turned against friend. Old grievances resurfaced and added to the flames until they burned out of control. I eventually identified five groups actively attacking the others. One of the groups formed a password protected internet forum where the members candidly criticized those not in the group. Someone leaked the password and the explosion shattered what congregational cohesiveness remained. They were no longer interested in conflict resolution and nothing I or my team could do changed it. The church building today is a bed and breakfast and the congregation no longer exists.

In every case, friendships have been severely damaged and each side believes it has been attacked viciously and unfairly. Trusting again seems unreasonable. They are depressed, angry, disillusioned, fearful, and in emotional pain, and they have redefined each other's humanity by lowering it. Surprisingly, these provide the entry point for intervention. 


\section{The Crucible Process Explained}

There is a preparation process of individual interviews that must be completed to prepare the ground, gain a deep understanding of the damage that has been done, and to build rapport and trust with each participant before beginning the formal Crucible. The Crucible is full day process where all participants are in the same room for the duration. The five steps within the Crucible are identified by the acronym TRUTH = Turning, Remembering, Understanding, Transforming, and Healing.

The entry point for this fourth way is focused, not so much on the behaviour of those involved, but on how that behaviour harmed others in terms of physical symptoms, and emotional, relational, and spiritual pain. The Peacemaker gains this information through one-on-one confidential interviews; in each interview, the disputants are independently asked to tell their story, including how they feel, what physical and emotional symptoms they have, what they will do if the matter is not resolved, and their willingness to meet in a safe setting with those who have opposed them. It requires as many interviews as possible from all levels over the course of three full days: elders, deacons, office staff, parishioners, lay leaders and even the janitor. I interview the pastor last. By then I have a clear picture of what has happened-and the pastor is the primary problem about $30 \%$ of the time (Puls and Ball, 2015.)

The information is compiled verbatim into four lists: physical reactions, emotional reactions, spiritual reactions, and the future if not resolved, forming a "litany of misery". Reading it is heart breaking. On it will be symptoms such as diarrhoea, vomiting, migraine headaches, depression, over eating, betrayal, unbearable fatigue, nightmares, etc. The patterns of conflict, damage to the people, and the future of the church if the conflict is not resolved become obvious.

\section{The Crucible, Step One: Turning}

All members of that faith community are invited to participate in a full-day interactive future search with the Peacemaker and church leaders. This type of intervention requires a minimum of six hours contact time between the disputant participants and the Peacemaker intervenor. It is most effective when done in a single day.

They meet in a carefully arranged room. The seating is circular, with concentric circles as necessary. The circle cuts down on side conversations, but its primary purpose is creating a space where all the participants can see each other. In the centre is a table with important artefacts of their religious belief as the focal point. Opening words and a prayer for restored peace and relationships are offered by the pastor, who turns matters over to the Peacemaker(s).

The process is narrative driven. At each level, the Peacemaker addresses where they have been and where they are now going as they progress through the day. The narrative is carefully designed to pull them closer together, increase senses of trust and safety, and to encourage the participants. Each level builds on the previous level, and increases in intimacy and intensity. (The process is fully described in Puls, 2013).

In Truth, the Peacemaker describes what has happened without attributing blame. The seating 
arrangement and litany of misery come together as the Peacemaker reads verbatim what they have told him or her to the entire group. A phenomenon occurs at this point that destabilizes their hardened positions: as people hear their symptoms, they tend to react slightly but visibly. Being in a circle, this becomes powerful when "enemies" see each other reacting. They have been self-focused and the tendency is to believe that their "enemy" is enjoying the fight while they are miserable. The jarring reality of shared misery begins the rehumanization process and tends to end feelings of isolation (LaBianca et al., 1998). The intensity increases as they begin to understand that their emotional pain and physical discomforts are universal, self-inflicted, and may destroy a place they have loved if the situation is not resolved.

The Peacemaker then asks if it is possible that each one of them may have said, thought, or done something that might have made matters worse. The equivocation in the question allows them space for a soft "yes" that may or may not be stated. The Peacemaker then invokes the words of Jesus: "But I say to you, Love your enemies and pray for those who persecute you" (Matthew, 5:44). The participants are then asked to "pray for your enemies in this fight, that God might heal them and bless them beyond their wildest imagination" for 3 to 4 minutes. At the end of the time, the Peacemaker asks, "All of you prayed for someone. Who prayed for you? Who has seen you as an enemy to be feared and avoided?" Once again, cognitive dissonance shakes their thinking by introducing the reality that each has been apprehended as an enemy when each wants the "other" to be the enemy and reserve for themselves the powerful role of victim. Their focus has been outward, but now begins to turninward.

\section{The Crucible, Step Two: Remembering}

In Remembering, each participant states something they did without any explanation of why it was done, just a simple "I gossiped." This simple truth arouses curiosity and surprise, and makes forgiving easier as these unadorned facts begin to clear away the dross of conflict (Graybill, 1998, p.111). Confession moves people from "a third-person stance of holding people accountable to a first-person stance of accepting responsibility" (Jones, 1995, p.147).

The collective confession makes this truth undeniably clear: They have been their own worst enemies, they have hurt themselves and each other, and their pain is universal. This realization draws them in tighter and begins the process of re-forming their perceptions away from the groups and positions taken, to a more inclusive view where each has suffered loss. What was the singular-and isolated-you and me is quickly becoming the inclusive we.

\section{The Crucible, Step Three: Understanding}

Understanding is the most powerful stage of the process. Tension has been building but a sense of sadness, of mourning begins to fill the room. If the Peacemaker has made their meeting into a sacred space, it will be safe to proceed. As their sense of safety increases, so too does their sense of doing something sacred that offers the possibility of redemption and reconciliation. It is here where they begin to find hopeagain. 
Understanding is that deep upwelling of sorrow in acknowledging and accepting the damage one has caused and received. The coupling of confession and sorrow become evident in Psalm 38:18, where David writes, "I confess my iniquity; I am troubled by my sin." While confession is usually a verbal statement, sorrow may be verbal or nonverbal and expressed in many ways. It only requires that it is expressed in some manner. We call it apology. In it the offender seeks something that he depends on the victim to supply: acceptance and forgiveness. This lament, then, is the essence of humility carried into action as it is offered without the surety of acceptance. A refusal to admit error and sorrow in humility will cause the apology to fail.

Everyone is asked to state to the group something that hurt them deeply, and the results of the wounding, but without attribution or blame. Anonymity makes it possible to get them communicating silently but directly with each other, as the person who caused the pain usually knows it is him or herself who is being referenced. This winsome act of undefended sorrow breaks down the barriers to relational repair by admitting what they did, and sorrow for the damage and pain it caused. Jones terms this as redemptive speech and states that if disputants approach each other " $\ldots$ in the context of forgiven lives and redemptive speech," they can more readily deploy the "power of Christ's cross and resurrection rather than powers of domination" towards forgiveness and reconciliation (Jones, 1995, p.190).

My practice is to tell the story of two physicians, male and female, who asked me to mediate their dispute. The process became stuck at a particularly vulnerable place. I sought the deepest pain from their fight, but both resisted. Finally, I had the male describe his family and how it coped with conflict. $\mathrm{He}$ related how they thought it was almost a competition to yell with their noses inches apart, to invade each other's space, and in general try to intimidate each other. Arguing was a contact sport, and he saw it as normal behaviour. I asked how he had last argued with Dr. Smith. He demonstrated by going over the table towards her-and I saw her already small body shrink in fear. I asked her, "What happens when you are yelled at?" In a tiny child's voice, she whispered, "You get hit." She was terrified of his "normal behaviour." His surprise was total. He looked as if a horse had kicked him in the gut, and could only sputter parts of words, but his sorrow was immediate and deep. He had reached understanding, as did she a bit later. They forgave each other, and started to reconcile. Over time, and with my coaching, they built a new, stronger relationship on the ashes of the old. Eighteen years later they still practice medicine together, and recently she said to me, "It is amazing what can happen when God gives you new eyes to see with.”

The foundations for sorrow, or contrition, statements are in passages such as Psalm 51:17, which says, "The sacrifices of God are a broken spirit; a broken and contrite heart, O God, you will not despise." A contrite heart is sorrowful, even penitent, and desiring to change for the better, but without any excuses; it is to stand naked in the court of human judgment.

In Understanding, we weave a complex song of lament and mourning, but one also tinged by hope. It is common to have people crying, but it is equally common for their (now) former enemies to offer comfort. 


\section{The Crucible Step Four: Transformation}

Transformation is the point where trust begins to be rebuilt. Why should I again trust you? This question goes to the centre of mending torn relationships - those who ask it seek assurance that they will not be victimized again. The question may seem difficult to answer at first. What does assurance look like? What is its shape? The one asking the question already knows the answer. He or she may not have articulated it yet, but the answer is there. The Peacemaker's job is to help them find and expressit.

The temptation is to ask what each will do to rebuild trust, but that question is premature. The better question is: "How has this event changed you? What have you learned from this that you pledge to do differently the next time conflict occurs?" This introduces a different form of confession, one that promises change and seeks commitment. Promising to change in front of witnesses translates into actual change as it commits them to new behaviours in front of all, which immediately forms a sense of accountability and mutual commitment. (Baumeister et al., 1998, pp.203-4). The community is beginning to re-form itself.

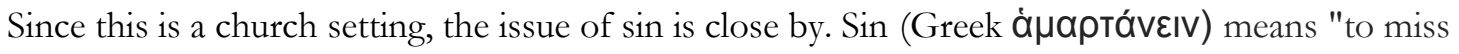
the mark" or "to err," and nothing more. The effects of sin in this instance are most important: broken relationships. Transformation recognizes that they have sinned against God and each other. The confession of sin says: "I hurt you, and it was deliberate." It is short, unadorned, and utterly repugnant. Apology soothingly says: "What I did was wrong, and I am sorry." Transformation more endearingly proclaims: "I learned. I changed. Never again."

It is also here where specific requests for change are made, but with an added, "what do you need from me?" We are now creating an intimate dialogue as they make requests for specific things from each other.

\section{The Crucible, Step Five: Healing}

We have now arrived at the final, most fluid, and creative level: Healing through mercy and justice. In this setting mercy and justice are inseparable and have their roots in two short passages from the Jewish Bible: "He has shown you, O mortal, what is good. And what does the LORD require of you? To act justly and to love mercy and to walk humbly with your God" (Micah 6:8). "Mercy and truth are met together; righteousness and peace have kissed each other" (Psalm 85:10). As John Paul Lederach, an early pioneer in forgiveness studies, so poignantly insists, justice and mercy are not an either/or proposition they are inseparably intertwined and the fruits of much labour (1997).

Justice takes by force that which might be freely offered if the offender saw a chance for redemption. Forgiveness offers that hope. Regarding revenge, "The fundamental fact is that the act that is 'done back' and is supposed to 'restore a balance' and 'make things right' or 'bring justice' is still, in the end, wrong" (Govier, 2002, p.14). In what was probably received as one of the most outrageous things he ever said, Jesus demanded that his followers not only tolerate, but actively love and pray for their enemies (Mt. 5:43-44). Paul echoes Jesus when he exhorts the church in Rome to "not repay anyone evil for evil. ..” (Rom, 12:17). 
Punitive justice offers little incentive to change if it contains no chance for restoration and redemption (Kelin \& Ellard, 1999, p.869). Merciful justice, however, makes the concrete rules of justice more slippery and elastic, opening the way to creativity and nuance.

In the Christian Bible, we find the following: "Brothers, if anyone is caught in any transgression, you who are spiritual should restore him in a spirit of gentleness" (Gal. 6:1). Love modifies justice through mercy, moving away from lock-step rules of penalties and punishments and into the fluid and ever-changing realm of restoration. Justice says: "I must punish you in equal measure to what you did." Mercy says: "I value you and our relationship above what you took from me. I will restore you." Thus, justice and mercy are no longer separate but combined into an intimate relationship, the final act in this ever more intimate dance of guilt, sorrow, forgiveness, andredemption.

Christian congregations, then, must see justice not as a separate and distinct process, but as inherently part of a restorative process, with the pure grace of mercy transcending simple punishment. Otherwise, the behaviours leading up to this point of vulnerability (repentance, confession, apology, and transformed behaviour) are an exercise in futility as there is no hope of forgiveness. For Christians, forgiveness must be an integral part of justice-seeking, for there can never be justice that satisfies. Forgiveness forges new bonds where old ones are broken rather than repairing old bonds, thus offering new opportunities for relationships to grow beyond where they were prior to their breaking.

And so, we engage in the final step: We open ourselves to the justice of those we have harmed, offering no defences, but hoping for mercy. The Peacemaker discusses justice and mercy as a healing continuum, and makes his final request: Go to the person or persons you were most angry with, and ask them this single, simple question: "What can I do to make this right between us?" In our experience, the most common answer is: "You just did it" which is often followed by a tearful embrace.

\section{After the one-day session - The Covenant}

In mediation, the goal is a settlement agreement, which is a legally binding document. However, as Christians who have come through the fire together, we strive for a written Covenant, which is a holy set of promises and statements where we commit to one another and to God to move forward together, to seek harmony through discord, to listen more than we speak, and to pray together regularly. In it we agree to be held accountable, but also to gently correct when we stray. These promises are made before God and each other, and form the core of the new relationships we are entering into in the reconciled community. Often, the Covenant will reference the early Church in Acts 2:43-47 and 4:32-37.

It is now up to the participants to form the covenant. They may do this as a large group (I had one group with more than 100 people who created a lasting covenant over the course of several weeks) or may select trusted representatives to work through the process. The final covenant is signed by all. In our experience, all but the most important issues fall by the wayside, and they find it relatively easy to solve together the real problems that they face. They are no longer enemies, but partners. We remain available to assist them as needed. 


\section{References}

Baumeister, R. F., A. M. Stilwell and T. F. Heatherton (1998) "Personal Narratives about Guilt: Role in Action Control and Interpersonal Relationships" in Worthington, E.Jr. (ed.) Dimensions of Forgiveness: Psychological Research and Theological Perspectives. Philadelphia: Templeton Foundation: 202-204.

Bush, Robert A. Baruch and Joseph P. Folger (1994) The Promise of Mediation: Responding to Conflict Through Empowerment and Recognition. San Francisco: Jossey Bass.

Bush, Robert A. Baruch and Joseph P. Folger (2004) The Promise of Mediation: Responding to Conflict, Revised Edition, San Francisco: Jossey Bass.

Celano, C., R. Millstein, C. Bedoya, B. Healy, A. Roest, J. Huffman (2015) “Association Between Anxiety and Mortality in Patients with Coronary Artery Disease: A Meta- Analysis". The American Heart Journal 170(6) (Dec): 1105-1115.

Coyle, C. and R. Enright (1997) "Forgiveness Intervention with Postabortion Men".

Journal of Counseling and Clinical Psychology 65(6): 1042-1046.

Enright, R. and R. Fitzgibbons (2002) Helping Clients Forgive. Washington, DC: American Psychological Association.

Fitzgibbons, R. (1998) “Anger and the Healing Power of Forgiveness: A Psychiatrist's View”, pp.63-74 in

R. Enright \& J. North (eds.) Exploring Forgiveness, Madison, University of Wisconsin.

Govier, T. (2002) Forgiveness and Revenge. New York, Routledge.

Graham, J., L. Christian, J. Kiecolt-Glaser (2006) "Stress, Age, and Immune Function: Toward a Lifespan Approach". Journal of Behavioral Medicine 29(4): 389-400.

Graybil, L. (1998) "The Pursuit of Truth and Reconciliation in South Africa", Africa Today 45(1): 103-133.

Halverstadt, H. (1991) Managing Church Conflict. Louisville, Westminster John Knox.

Kelin, B. and J. Ellard (1999) "An Equity Theory Analysis of the Impact of Forgiveness and Retribution on Transgressor Compliance", Personal and Social Psychology Bulletin 25(7): 864-872.

Isaacs, W. (1999) Dialogue and the Art of Thinking Together. New York, Currency Doubleday.

Jones, L. G. (1995) Embodying Forgiveness: A Theological Analysis. Grand Rapids, Baker.

Kale, D. (2003) Managing Conflict in the Church. Kansas City, Beacon

Labianca, G., D. Brass, and B. Gray (1998) "Social Networks and Perceptions of Intergroup Conflict: The Role of Negative Relationships and Third Parties", Academy of Management Journal 41(1): 55-67.

Lederach, J. P. (1997) The Meeting Place (draft). Online. Available at:

http://www.colorado.edu/conflict/transform/jplchpt.htm.

Lin, W.F., D. Mack, R. Enright, D. Krahn, and T. Baskin (2004) "Effects of Forgiveness Therapy on Anger, Mood, and Vulnerability to Substance Use Among Inpatient Substance-Dependent Clients". Journal of Consulting and Clinical Psychology 72(6) (December): 1114-1121. DOI: 10.1037/0022006X.72.6.1114.

McGarrigle, M. and P. O'Connor (2015) "Restorative Practice in Education - Transform Puls, D. (2008a) "Breakthroughs, Benefits, and Backfires of Apology in Medical Malpractice Litigation", Paper presented to, Pacific Currents and Sound Perspectives, American Bar Association National Dispute Resolution 
Conference, Seattle, WA April 4, 2008.

Puls, D. (2008b) "Expanding the Borders of Restorative Justice", Justice Connections Quarterly 6: 7-9.

Puls, D. (2013) The Road Home: A Guided Journey to Church Forgiveness and Reconciliation, Eugene, OR:

Cascade Books.

Puls, D., \& R.Glen Ball, (2017) "The Frequency of Narcissistic Personality Disorders in Pastors: A Preliminary Study." Original research paper presented to the American Association of Christian Counsellors World Conference, Nashville, TN. (Sept. 27, 2017)

Roozen, D. (2008) Faith Communities Today 2008: A First Look. [online] Hartford Institute for Religion

Research. Available at:

https://faithcommunitiestoday.org/sites/all/themes/factzen4/files/FACT20081stLook .pdf.

Roozen, D. (2015) American Congregations 2015: Thriving and Surviving. [online] Hartford Institute for

Religion Research. Available at: http://hirr.hartsem.edu/American-Congregations-2015.pdf.

Stowe, M. (2016) “A Restorative Trail: Restorative Practice -opening up new capacities of hearts and minds in school communities", Journal of Mediation and Applied Conflict Analysis 2 (1)

Susek, R. (1999) Firestorm: Preventing and Overcoming Church Conflicts. San Francisco, Jossey Bass.

Therani, N. (1998) "Dealing with Trauma at Work: The Employee's Story". Counselling Psychology Quarterly 11(4): 365-78.

Thoreson, Carl E., Alex H.S. Harris and Frederic Luskin, (2000) "Forgiveness and Health: An Unanswered Question," in Forgiveness: Theory, Research, and Practice, ed. Michael E. McCullough, Kenneth I. Pargament and Carl E. Thoreson, New York: Guilford, 254-

280.

Toussaint, L., A. Owen, and A. Cheadle (2012) "Forgive to Live: Forgiveness, Health, and Longevity". Journal of Behavioral Medicine 35(4) (Aug): 375-86.

Umbreit, Mark S., Robert B. Coates and Betty Vos, (2004) "Victim-Offender Mediation: Three Decades of Practice and Research," Conflict Resolution Quarterly, 22, (1-2): 279- 303.

Vandergrift, S. (2013) The Top 4 Things People Want From Your Church. Church Leaders [online] Available at http://churchleaders.com/pastors/pastor-how-to/165140-shawn- vandergrift-top-4-things-people-wantfrom-your-church.html.

Van Yperen, J. (2002) Making Peace: A Guide to Overcoming Church Conflict. Chicago, Moody.

Wellikoff, Ilyssa. (2002) "Victim-Offender Mediation: On the Way to Justice." Cardozo Journal of Conflict Resolution 5(1), Quoting Lorenn Walker, "Conferencing: A New Approach for Juvenile Justice in Honolulu”, Federal Probation Journal, 66 (1), June 2002

Weinberg, N. (1995) “Does Apologizing Help? The Role of Self-Blame and Making

Witvliet, C. (2001) "Forgiveness and Health: Review and Reflections on a Matter of Faith, Feelings, and Physiology", Journal of Psychology and Theology 29(3): 212-228.

Zehr, Howard (1990) Changing Lenses: A New Focus for Crime and Justice, Scottsdale, PA: Herald Press 


\section{Biography}

Darrell Puls holds an earned doctorate in religious conflict management from Trinity Theological Seminary and has been a conflict management professional for more than 40 years in various capacities, including mediator at federal and local levels, police hostage negotiator, organizational conflict analyst and interventionist, researcher, and peacemaker. His work in post-conflict forgiveness and reconciliation processes has gained international recognition. He is currently expanding field research into Narcissistic Personality Disorder in the clergy with a book to be published shortly. His work is published in textbooks, magazines, peer-reviewed journals, and online. Dr. Puls currently serves as Dean of Academic Affairs at a small, private Christian college in Washington State. 